\title{
Explaining support for Brexit among parliamentary candidates: The case of Wales
}

\section{Siim Trumm (University of Nottingham)}

Journal: British Politics

Date of acceptance: 17/02/2020

\begin{abstract}
The 2016 EU referendum was a key moment in the history of the United Kingdom. It has changed the course of the country and continues to define political battlegrounds. Despite research on which voters cast their ballot for Leave having become a minor industry in recent years, we still know little about what factors motivated our politicians to do so. Using original data from the 2016 Welsh Candidate Study, this paper explains support for Brexit among parliamentary candidates in Wales. It finds that both candidates' socio-economic profile and political attitudes influenced their decision to vote Leave in 2016. The strongest determinants of Leave vote were candidates' views on how the EU works; how democratic it is and how much influence it can exert. Candidates' occupational background and policy concerns were also relevant, but their effects were slightly weaker. These findings highlight that there are important similarities between what influenced politicians and voters to cast their ballot for Leave, but also some salient differences.
\end{abstract}

Keywords: Brexit, parliamentary candidates, democracy, sovereignty, Wales 


\section{Introduction}

On 23 June 2016, the United Kingdom (UK) voted to leave the European Union (EU). It was a key moment in the history of the UK and European (dis)integration, setting into motion developments that have already cost a premiership and helped a four-month-old party win a national election. Brexit continues to dominate the political discourse, define political allegiances, and divide the country.

The importance of Brexit in shaping the future of the UK and its political discourse has unsurprisingly led to an ever-growing number of academic studies examining who voted for Leave at the $2016 \mathrm{EU}$ referendum. These studies tend to either use individual-level survey data to examine how voters' socio-economic characteristics and political attitudes related to their voting choice (Clarke et al. 2017; Henderson et al. 2017; Hobolt 2016), aggregate local-level data to explore whether Leave vote varied across communities with different demographic profiles (Goodwin and Heath 2016; Matti and Zhou 2017), or both (Goodwin and Milazzo 2017; Lee et al. 2018). What they share, however, is their focus on voters. Yet, while we know how many politicians voted at the EU referendum, we still know little about what factors shaped their decision to support Leave versus Remain. What influenced politicians to cast their ballot for Leave? Are the factors explaining Leave vote among politicians and voters the same or not?

This study explores how important socio-economic background and political attitudes were in shaping support for Leave among parliamentary candidates, focusing on the case of Wales. ${ }^{1}$ It does so by using original data from the 2016 Welsh Candidate Study. Given that this survey was conducted in

\footnotetext{
${ }^{1}$ There are two benefits to focusing on Wales. First, it provides insight into Leave versus Remain support in a nation that was most divided at the EU referendum. Second, there is unique survey data from Wales that capture the political views and personal characteristics of candidates of different parties in the immediate run up to the EU referendum. To the best of my knowledge, no other elite survey data of this kind is currently available. That said, the focus on candidates at one particular devolved election does of course limit the scope of this study and the generalisability of its findings.
} 
May-June 2016 and included questions on candidates' voting intention at the EU referendum, political attitudes and personal background, it offers an opportunity to systematically evaluate the comparative relevance of different types of explanatory characteristics in motivating candidates to cast their ballot for Leave.

The empirical findings reveal that both candidates' socio-economic background and political attitudes influenced whether they cast their ballot for Leave or Remain. Candidates were more likely to vote for Leave if they were critical of how democracy works in the EU and if they thought that the EU has too much influence over the way Wales is run. Moreover, voting for Leave was higher among candidates who believed immigration-related issues to be among the key concerns facing Wales and who saw their occupational background as non-specialist (versus managerial or professional/technical). These findings emphasise that there was no single reason that explains Leave vote among politicians. It was concentrated among politicians with a certain occupational background, but it was also influenced by their political attitudes and policy concerns.

This article is organised as follows. In the next section, existing literature on Leave vote is examined and theoretical expectations outlined. I then describe the data and operationalisation of the variables. This is followed by the presentation of empirical results. The paper concludes with a discussion of the implications that emerge from the empirical analysis.

\section{Who voted for Leave?}

There is a growing body of literature that seeks to explain why some voters cast their ballot for Leave and others for Remain on 23 June 2016. They may use different approaches, focusing on individual voters or constituencies as the units of analysis, but their findings tell a very similar story about who were more likely to cast their ballot for Leave.

First, a number of socio-demographic characteristics have been found to systematically correlate with voters' likelihood of casting their ballot for Leave. It is widely accepted that Leave support was higher 
among older voters (e.g., Goodwin and Heath 2016; Henderson et al. 2017; Hobolt 2016; Matti and Zhou 2017)², the less educated (e.g., Arnorsson and Zoega 2018; Goodwin and Heath 2016; Goodwin and Milazzo 2017; Hobolt 2016), and those holding a weak European identity and/or a strong national one (e.g., Carl et al. 2019; Curtice 2017; Goodwin and Milazzo 2017; Henderson et al. 2016; Hobolt 2016). The existing evidence with regards to whether voters' occupational background and gender influenced their likelihood of voting Leave is mixed (Clarke et al. 2017; Goodwin and Milazzo 2017; Hobolt 2016; Matti and Zhou 2017; Vasilopoulou 2016). Existing research into Leave vote has shown that Leave voters shared a slightly different demographic profile than their Remain counterparts.

Second, existing studies have also shown that political attitudes had significant influence over voters' likelihood of casting their ballot for Leave versus Remain. In particular, it is voters' attitudes towards immigration that stand out. It has been shown that support for Leave was higher among voters who were concerned about immigration and its impact on the UK (e.g., Arnorsson and Zoega 2018; Goodwin and Milazzo 2017; Hobolt 2016; Vasilopoulou and Keith 2019). ${ }^{3}$ In addition, existing studies have found Leave vote to be associated with negativity about the political system and how it works (e.g., Bromley-Davenport et al. 2018; Hobolt 2016; Vasilopoulou and Keith 2019), desire for greater national-level control over legislative decision-making (Hobolt 2016), right-wing ideological stance (Vasilopoulou 2016; Vasilopoulou and Keith 2019), positive assessment of the impact that leaving the EU will have (e.g., Clarke et al. 2017; Curtice 2017; Henderson et al. 2017; Hobolt 2016), and negative evaluation of the impact that being in the EU has had (Hobolt 2016; Vasilopoulou 2016;

\footnotetext{
${ }^{2}$ The exception here is the study by Goodwin and Milazzo (2017) that did not find a systematic effect associated with age on someone's likelihood of voting Leave.

${ }^{3}$ It has also been shown that Leave vote was higher in regions where immigrants made up higher proportions of the population (Colantone and Stanig 2018; Goodwin and Heath 2016).
} 
Vasilopoulou and Wagner 2017). Taken together, voting for Leave is seen to have been influenced by voters' personal profile as well as political attitudes. ${ }^{4}$

The existing evidence on what factors influenced whether politicians cast their ballot for Leave or not, however, is much more limited. Recent studies by Heppell et al. (2017), Lynch and Whitaker (2018), and Moore (2018) have started exploring this. Their findings suggest that political attitudes stand out as consistently influential in explaining support for Leave, whereas the evidence regarding politicians' personal and political profile is more mixed. Heppell et al. (2017) find very little evidence that socioeconomic demographics mattered and the only significant aspect of political profile was whether one was a government minister or not, while Lynch and Whitaker (2018) find past parliamentary voting choices and ministerial status to have influenced whether politicians voted for Leave or not. Finally, Moore (2018) shows that voting for Leave was less likely among first-time and frontbench MPs, and those who represented constituencies with weaker Leave support. All of these studies, however, only focus on the members of the parliamentary Conservative Party. This is unsurprising as the European issue has had a profound effect on the Conservative Party in recent decades (Cowley and Stuart 2012; Heppell 2013; Lynch and Whitaker 2013), but it does mean that the already-limited evidence derives also from a very narrow political spectrum. ${ }^{5}$

The existing evidence from the supply side also comes from a limited range of political actors, elected representatives. Whilst it is important to know and understand how our elected representatives behave and what they think, the cues that voters receive from and the interactions they have with the "political class' go beyond politicians who are electorally successful. All candidates, albeit with varying levels

\footnotetext{
${ }^{4}$ A similar mix of factors have also been found to influence voters' desire for renegotiating EU membership and support for the EU more broadly (Vasilopoulou and Keith 2019; Vasilopoulou and Talving 2019).

${ }^{5}$ The recent study by Crines et al. (2018) looks at the EU referendum vote of the members of the parliamentary Labour Party, but only in the context of whether it had an effect on their support for Jeremy Corbyn in the 2016 confidence motion and the following leadership context or not.
} 
of effort, seek to engage with voters and represent them. Therefore, it is important to extend the scope of actors whose views are taken into account when examining the preferences of those who are on the supply side of the voter-elite equation.

Despite research on who voted Leave having become a minor industry, it still has limitations. On the one hand, this literature has predominantly focused on voters and why they decided to cast their ballot for Leave or Remain. Whereas this is of course essential to understand, it does not allow us to assess whether the reasons for voting for Leave were similar or different among voters and those who seek to represent them. It is widely acknowledged that politicians were 'out of touch' by voting for Leave in smaller numbers than the electorate as a whole (PoliticsHome 2016), but it remains unknown whether they were also 'out of touch' in terms of their motivations for voting Leave when doing so. On the other hand, the discussions that are being had about which politicians supported Leave focus on their publicly stated EU referendum vote choice and a limited range of explanatory factors. The former can be problematic to describe politicians' sincere beliefs as positions that become public may be influenced by considerations of how one's party and voters react to them (e.g., Hug 2013; Schwarz et al. 2017; Trumm 2015). Moreover, a broader range of explanatory factors should be accounted for when explaining politicians' EU referendum vote choice. For example, existing studies do not control for how democratic they perceive the EU to be and how much control it is seen to exert, despite both having been prominent parts of the Leave campaign. It is, therefore, important to build on the growing body of literature from the voter side and examine the importance of a broader range of factors, socioeconomic characteristics and political attitudes, in influencing politicians to vote for Leave. Finally, it is important to look beyond electorally successful politicians when examining the views of those who seek to engage with and represent voters. This study does so by focusing on parliamentary candidates in Wales.

\section{Expectations}

The expectations follow what existing studies of voters have uncovered. There is no reason to believe that patterns of voting for Leave were different among parliamentary candidates. Support for Leave is 
expected to be stronger among male candidates, those who are older, do not have a university degree, are more right-wing, and have a non-specialist occupational background. With regards to political attitudes, Leave vote should be higher among candidates who are more critical of the state of democracy in the EU and the level of influence it exerts, and who consider immigration as a key issue facing Wales. Table 1 summarises these expectations, expressed in relation to voting for Leave.

[TABLE 1 HERE]

\section{Data and methods}

The theoretical expectations are evaluated using the 2016 Welsh Candidate Study. It is a post-election survey of candidates who stood for election to the National Assembly for Wales in May 2016. Given the timing of the devolved election, the survey was conducted also in the immediate run up to the EU referendum. The sample of 111 candidates used in the analysis is representative of the full population of candidates. ${ }^{6}$

There are multiple advantages in using survey data from the 2016 Welsh Candidate Study to examine Leave vote among politicians. First, it provides insight into their voting choice, personal background, and, crucially, political attitudes in the immediate run up to the EU referendum. Whereas information on the first two is publicly available, individual-level information on politicians' key policy concerns, their views on how well democracy works in the EU, the level of control the EU ought to be able to exert, etc. is not. The 2016 Welsh Candidate Study provides information on all these three types of aspects immediately before the EU referendum. Second, the survey also captures candidates' sincere views. Candidates were assured that their responses are treated confidentially and are not be disclosed in a manner that would allow the identification of individual respondents, meaning that they did not have to be concerned about what their party and voters might think of their views. Unlike any public

\footnotetext{
${ }^{6}$ Further information about the sample is provided in Appendix A.
} 
declaration of political preference, the confidential nature of the survey responses means that the data used in this study captures candidates' unbiased, sincere opinions.

The reliance on the 2016 Welsh Candidate Study offers a unique research opportunity, but it does also call for caution. The nature of the 2016 Welsh Candidate Study, conducted in relation to the devolved election in Wales, means that the analysis undertaken here relies exclusively on candidates from one part of the UK and who are not as high profile as their counterparts who are running for office at general elections. Therefore, one must be conscious of not generalising too much beyond the specific findings presented here. That said, the novelty of this survey and its data offer a first-cut insight into what factors shape support for, and opposition to, Brexit among people who seek to represent us.

\section{Dependent variable}

The dependent variable in this study is Leave vote. It is a straightforward indicator that distinguishes between candidates who planned to vote Leave (coded 1$)$ or Remain (coded 0$)$ at the EU referendum. ${ }^{7}$ Candidates who did not intend to vote or were undecided about how they would vote were excluded from the analysis. As such, only those candidates who expressed a clear commitment to voting Leave or Remain were included.

\section{Explanatory variables}

Three sets of explanatory variables are included in the analysis. First, it accounts for the demographic profile of the candidates. Gender is operationalised as a dichotomous variable, with female candidates coded as 0 and male candidates as 1 . Age describes how old candidates were at the time of completing the survey. Age groups are defined as follows: 1 '18-34 years old', 2 '35-54 years old', and 3 '55+ years old'. Education distinguishes between candidates with a completed university degree (coded 1)

\footnotetext{
${ }^{7}$ Given the timing of the 2016 Welsh Candidate Study, the vast majority of the responses were received before the EU referendum.
} 
from those without one (coded 0). ${ }^{8}$ Next, occupation describes candidates' occupational background. It distinguishes between candidates whose self-perceived occupational background is non-specialist (coded 0 ), professional or highly technical (coded 1), and managerial (coded 2). ${ }^{9}$

Second, a number of explanatory variables are included to capture candidates' political attitudes and policy concerns. Evidence from the British Election Study shows that three policy areas - economy, immigration, and sovereignty/EU bureaucracy - stood out as the most important ones in determining EU referendum position (Evans et al. 2016). Therefore, economy separates candidates who mentioned economic issues as the most important or second most important problems facing Wales (coded 1) from those who did not (coded 0), and immigration captures whether they considered immigration as the most important or second most important problem facing Wales (coded 1) or not (coded 0). Those concerned with economy are expected to vote for Remain in disproportionally high numbers, whereas concerns with immigration should lead to greater likelihood of voting for Leave. Next, I include three indicators - Wales democracy, UK democracy, and EU democracy - that capture how satisfied one is with the way democracy works in, respectively, Wales, UK, and the EU. These indicators range from 1 'very satisfied' to 4 'not at all satisfied'. Finally, EU influence describes the level of control that the $\mathrm{EU}$ is perceived to have over the way Wales is run, ranging from 1 'too little' to 3 'too much' ${ }^{10}$, and ideological position captures candidates' self-placement on the 0 'left' to 10 'right' ideological scale.

\footnotetext{
${ }^{8}$ I opted against a further distinction between candidates without a university degree due to the small number of candidates who would have fallen into each of the more specific non-university categories.

${ }^{9}$ The non-specialist reference category encompasses candidates who describe their occupation as something that does not require extensive training or involve senior management (e.g., manual labour, clerical work, sales), and those who have never had a job. Whereas studies of voters have sometimes split this non-specialist category into further sub-categories, this is not practical here due to the limited number of candidates who would fall into each of the more specific non-specialist categories.

${ }^{10}$ The 2016 Welsh Candidate Study asked respondents to rank different institutions by the level of influence they are perceived to currently have over the way Wales is run and the level of influence they ought to have over
} 
Finally, candidates' political experience is controlled for. Past AM captures whether candidates have been Assembly Members at any point before the 2016 devolved election (coded 1$)$ or not (coded 0$).{ }^{11}$ Given that Wales benefits from the EU's budget (Wales Governance Centre 2016), it is reasonable to expect that candidates who have had first-hand insight into the additional opportunities it provides for Wales, through their role as Assembly Members, are likely to be more positive about EU membership than those without such experience.

\section{Empirical strategy}

The potential effects of the explanatory variables on candidates' decision to vote for Leave or Remain are evaluated using a multivariate logistic regression model with robust standard errors.

\section{Findings}

The focus is now turned to explaining which explanatory factors had a systematic effect on voting for Leave. Table 2 presents findings from the multivariate logistic regression model.

It is evident that voting for Leave cannot be explained with any one characteristic. It is a function of multiple factors, related to candidates' socio-economic background as well as their political attitudes. In this sense, the initial picture that emerges is not different from what is accepted on the voter side; i.e., both demographics and political opinions matter (e.g., Becker et al. 2017; Goodwin and Milazzo 2017; Hobolt 2016). First, looking at factors related to candidates' demographic profile, most of these

\footnotetext{
the way Wales is run. EU influence measure combines candidates' responses to these two questions. Candidates are coded 1 'too little' if they rank the level of influence the EU ought to have higher than the level of influence it is perceived to currently have, 2 'about right' if they rank them equally, and 3 'too much' if they rank the level of influence the EU ought to have lower than the level of influence it is perceived to currently have.

${ }^{11}$ Estimates from models where past AM is operationalised as incumbents (coded 1) versus challengers (coded 1) are robust to those presented here and available upon request.
} 
are not systematically related to the EU referendum vote. ${ }^{12}$ I find no significant effects associated with gender, age, or education. That said, candidates' occupational background stands out when explaining their vote choice. The negative coefficients of -2.93 and -3.12 indicate, respectively, that candidates with professional/technical and managerial backgrounds were significantly less likely to cast a ballot for Leave than candidates with a non-specialist background, in line with the theoretical expectations.

Second, the findings regarding political attitudes are intriguing. Note first that a much broader range of factors have systematic effects on candidates' voting choice. In particular, candidates' attitudes on the EU stand out. The positive coefficient of 2.93 for EU democracy indicates that the more critical a candidate was of how democracy works in the EU, the more likely she was also to vote for Leave. ${ }^{13}$ In a similar vein, the positive coefficient of 3.14 for EU influence indicates that candidates who believed that the EU has too much influence over the way Wales is run were more likely to vote for Leave than those who were less critical of the extent of influence they believed the EU exerts over Wales. Both coefficients are significant at $\mathrm{p}<0.01$ level. Taken together, these findings clearly show that negative attitudes towards the EU were, as expected, key drivers for candidates' decision to cast their ballot for Leave.${ }^{14}$ Attitudes towards the EU are, however, not the only political attitudes that had a systematic

\footnotetext{
${ }^{12}$ The idea that only a sub-set of personal characteristics has a systematic effect on Leave support is broadly in line with the evidence from the voter side. Most studies of voters find the same and, even if they do find a broad range of personal characteristics to significantly shape Leave support, these effects tend to be weaker than those associated with voters' political views and attitudes.

${ }^{13}$ Respondents' views towards the state of democracy in Wales and the UK do not have significant effects on their EU referendum position. It is the evaluations of the EU, not the domestic political system, that are driving support for, or opposition to, Brexit.

${ }^{14}$ Interestingly, the evidence from the voter side is somewhat mixed. Whereas it is widely accepted that voters' attitudes and concerns regarding policy areas that are prominently linked to the EU in the public discourse, such as immigration, are crucial to understanding support for Brexit (e.g., Arnorsson and Zoega 2018; Goodwin and Milazzo 2017; Hobolt 2016), perceptions of how the EU works have not been found to systematically influence
} support for Brexit (Vasilopoulou 2016). 
effect on candidates' vote choice. Policy concerns also mattered. Whereas the negative coefficient for economy is in the expected direction, it fails to reach the conventional level of statistical significance $(\mathrm{p}=0.83)$. Concerns about immigration, however, have a statistically significant effect on candidates' vote choice. The positive coefficient of $3.73(\mathrm{p}<0.01)$ for immigration indicates that candidates who considered immigration-related issues to be among the key problems facing Wales were significantly more inclined to vote for Leave than those who did not believe that to be the case. This, again, is in line with the theoretical expectations and the existing evidence from the voter side. It lends further support to the claim that immigration was a key issue in deciding EU referendum position, and such concerns were associated with Leave vote.

Finally, the findings suggest that Leave vote was not concentrated disproportionately among political novices or political elites. One would have expected candidates who had been Assembly Members in the past and witnessed more closely the financial benefits that EU membership brings to Wales to be significantly less likely to vote Leave than candidates without such experience, but, interestingly, I do not find strong enough evidence to support this claim. The coefficient of 0.34 for past AM does not reach the conventional level of statistical significance $(\mathrm{p}=0.78)$. The evidence presented here suggests that candidates' decision to vote for Leave or Remain was not influenced by the experience of having been an Assembly Member. Taken together, the empirical evidence presented here suggests that support for Leave was mainly driven by candidates' political attitudes, rather than their personal and political background, even though the latter were certainly not irrelevant.

\section{[TABLE 2 HERE]}

To illustrate the real-world meaning of the findings and compare the effect sizes associated with the explanatory variables, Table 3 presents the predicted values for candidates' likelihood of casting their ballot for Leave. For each effect, the particular characteristic is allowed to vary, whereas all others are held constant at their mean for continuous variables or mode for nominal and dichotomous variables. 
The comparison of effect sizes further highlights that voting for Leave is multifaceted and cannot be explained with a single factor. That said, there does appear to be a hierarchy of effects. It is the effects associated with candidates' attitudes towards the EU and how it works that stand out once again. The strongest effect relates to candidates' assessment of the state of democracy in the EU. Candidates who were most critical about how democracy works in the EU were $67 \%$ more likely to vote Leave than those who were most satisfied with it $(67.1 \%$ versus $0.1 \%)$. Interestingly, the biggest increase $(35.8 \%)$ comes when comparing candidates who were 'not very satisfied' (31.3\%) to those who were 'not at all satisfied' $(67.1 \%)$. It seems that there was a distinct group of candidates who were quite critical of the state of democracy in the EU, but still voted for Remain in their majority. Only when sentiments about the state of democracy in the EU became overwhelmingly negative - 'not satisfied at all' - did candidates shift to supporting Leave in large numbers.

An effect of similar size is also associated with the other variable related to attitudes towards the EU. Candidates who believed that the EU currently has more influence over the way that Wales is run than it should have were much more likely to vote for Leave than those who believed that the EU ought to increase its influence over the way Wales is being run (60.2\% versus $6.6 \%)$. Interestingly, however, it is once again only the most negative attitude of 'too much influence' that is associated with a majority Leave vote. Candidates who believed that the level of influence the EU has over the way that Wales is run is about right are predicted to have voted Remain at roughly two-to-one $(60.2 \%$ versus $28.1 \%)$. It is clear that negativity about the EU and how it works was a key motivation for voting Leave, but the severity of the negative sentiments had to be considerable for candidates to vote for Leave in majority.

In terms of the other indicators, candidates' concerns about immigration and occupational background also have significant effects on their likelihood of voting for Leave. The effects here are much smaller than those discussed above, but still considerable. Starting with the former, candidates who believed immigration-related issues to be among the key policy concerns facing Wales were $28.1 \%$ more likely to support Brexit that those who did not $(69.7 \%$ versus $41.6 \%)$. In terms of occupation, candidates who had a non-specialist background were $22.4 \%$ more likely to vote Leave than those who self- 
classified their occupational background as professional/technical (64\% versus $41.6 \%)$ and $23.9 \%$ more likely to do so than those with a managerial background (64\% versus $40.1 \%)$. These effects are smaller than those associated with candidates' attitudes towards the EU, but they do contribute to our understanding of which politicians were more likely to vote for Leave. There was a majority support for Leave among candidates with salient concerns about immigration and non-specialist occupational background, but a majority support for Remain among those with other policy concerns as well as professional/technical or managerial occupational background. Taken together, political attitudes stand out as most influential in determining EU referendum vote choice among politicians, but one cannot discard the relevance, albeit a smaller one, of their socio-economic background.

\section{[TABLE 3 HERE]}

\section{$\underline{\text { Supplementary analysis }}$}

The analysis above demonstrated how different personal characteristics and political attitudes relate to candidates' likelihood of voting for Leave. Ideally, I would have also added partisanship to the list of explanatory factors used in the multivariate model. Given that the pool of candidates who stand at the devolved elections in Wales for each party is relatively small in the first place, and only a sub-section of them responded to the 2016 Welsh Candidate Study, the data do not allow it. However, I am able to provide a first-cut descriptive account of how support for Leave varied across candidates of different parties. Table 4 presents Leave support among candidates of different parties as well as the supporters of those parties. ${ }^{15}$

\section{[TABLE 4 HERE]}

\footnotetext{
15 This information derives from the 2016 Welsh Candidate Study for candidates and from the pre-election wave of the 2016 Welsh Election Study (Awan-Scully 2018) for voters.
} 
Note first that candidates of the different main parties, with the exception of those who ran under the Welsh Conservative Party label, are very united in their EU referendum voting choice. All candidates of Welsh Labour and the Welsh Liberal Democrats favoured Remain, as was the case with the vast majority of Plaid Cymru candidates (94.4\%), while all UKIP Wales candidates supported Leave in the 2016 EU referendum. A very different narrative emerges when looking at the Welsh Conservative Party candidates, as there is a clear division of views among them. Whereas most of them supported Leave (69.6\%), a significant minority opted for Remain instead (30.4\%). ${ }^{16}$

The broad trend among voters of different parties is similar to that of candidates. It is the same parties that stand out as least supportive of Leave - the Welsh Liberal Democrats (21.6\%), Welsh Labour (25.7\%), and Plaid Cymru (26.3\%) -, whereas the vast majority of UKIP Wales voters (96.1\%) supported Leave. There is an overwhelming preference for the same EU referendum position among the voters of these parties that was held by the vast majority, if not all, of their candidates. In contrast, the supporters of the Welsh Conservative Party are much more divided in their preference for Leave versus Remain, mirroring the division among its candidates. Whereas most of them supported Leave (64.4\%), a significant minority opted for Remain instead (35.6\%). The difference between the EU referendum position of different parties' candidates and voters appears to be effectively limited to the three most pro-Remain parties - the Welsh Liberal Democrats, Welsh Labour, and Plaid Cymru having a small, but notable, minority of Leave-supporting supporters, which is something that is not mirrored on the candidate side.

\footnotetext{
${ }^{16}$ A similar pattern is evident among elected Assembly Members. Kirsty Williams, solitary representative of the Welsh Liberal Democrats in Cardiff Bay, campaigned for Remain, there is overwhelming support for Remain among Plaid Cymru and Welsh Labour Assembly Members, and all candidates elected under the UKIP Wales banner backed Leave. The same unity was not evident among the candidates who were elected under the Welsh Conservative Party label, with the then-leader Andrew R.T. Davies, Darren Millar, and Mark Isherwood casting their ballot for Leave in contrast to many of their partisan colleagues in Cardiff Bay.
} 


\section{Conclusion}

The 2016 EU referendum has been one of the most divisive moments in the recent political history of the UK. Not only did the British electorate almost perfectly split between Leave and Remain, the question posed also divided political parties and politicians more broadly. In Wales, for example, we saw Andrew R.T. Davies, then-leader of the Welsh Conservative Party, campaign for Leave in contrast to most senior members of his party. Whereas we know quite a bit about which voters cast their ballot for Leave, much less is known about what influenced politicians to do so.

This study explored how important various socio-economic characteristics and political attitudes were in shaping support for Leave among candidates at the 2016 devolved election in Wales. It did so using original survey data from the 2016 Welsh Candidate Study. The findings reveal that candidates' views on the EU and how it works stood out as key determinants of the EU referendum vote choice. There is a significant increase in Leave vote associated with being critical about the state of democracy in the EU and the level of influence the EU can exert over Wales. In addition, the findings show that Leave vote was higher among candidates who saw their occupational background as non-specialist (versus managerial or professional/technical) and who considered immigration-related issues to be among the key problems facing Wales.

There are three broader points arising from this study and its findings. First, support for Brexit among politicians is a function of several factors. It is a story of their personal background, policy concerns, and perception of the EU. Future studies may very well expand this list, but it is already clear from the evidence presented here that there was no one, overarching motivation for politicians' decision to vote for Leave. It was a multifaceted decision and one that was shaped by different types of factors.

Second, the nature of the findings suggests that support for, or opposition to, Leave among politicians is likely to be very stable. The key drivers for voting Leave - evaluation of the state of democracy in the EU and the extent of influence the EU has - tap into fundamental scepticisms about the nature of the EU and its relationship with member states. Significant changes to how the EU works would most 
likely be required to win over those politicians who hold such negative perceptions about the EU $\cdot{ }^{17}$ It is reasonable to suggest, therefore, that there does not appear to be a quick or easy solution that would motivate politicians who voted Leave to change their mind.

Third, the findings reveal that there are both similarities and differences between what explains voting for Leave among politicians and voters. Socio-economic background and political attitudes are clearly both relevant to understanding Leave support among politicians as well as voters, with the latter being more influential among both groups. These are shared findings in both literatures. Where the findings seem to slightly diverge, however, is the nature of the political attitudes that drive support for Leave. Whereas voters' support for Leave is strongly linked to attitudes on policy areas that are associated with the EU, with immigration being the prime example, politicians' support for Leave is shaped more by their views on the EU as an organisation and how it works. The findings presented here do not suggest that there is a major gulf between what drives support for Leave among politicians and voters, but they do imply that there are subtle differences between the two.

These findings extend our understanding of who supports Brexit. They build on the existing evidence from the voter side and provide novel insight into what factors motivated politicians to vote for Leave. At the same time, they leave room and highlight the need for extending this research agenda. The very nature of the 2016 Welsh Candidate Study means that this paper focused on candidates from only one part of the UK. Future research ought to extend the scope of politicians whose views are examined

\footnotetext{
${ }^{17}$ There is some evidence from the voter side in Wales that changes to the UK's terms of EU membership could potentially influence support for Leave versus Remain. Public support for Leave exceeded that for Remain (45\% versus 37\%) in the closest Welsh Political Barometer prior to the approval of the UK's renegotiation of EU membership package in February 2016 (Awan-Scully 2016a), whereas the opposite was true (36\% versus 41\%) after it was approved (Awan-Scully 2016b). This does suggest, even if not prove, that preferences for Leave or Remain could potentially be revised as circumstances change.
} 
and assess the potential influence of additional explanatory factors on their decision to vote for Leave or Remain. 


\section{Appendix A. 2016 Welsh Candidate Study}

The 2016 Welsh Candidate Study includes 111 candidates for whom information on all variables that are included in the analysis is available. Duncan index of dissimilarity is used to show that the sample is representative of the full population of candidates. It ranges from 0 to 1 , and higher values indicate greater discrepancy between the sample and the full population (Duncan and Duncan 1955).

Table A1 shows the comparison between the sample used in the analysis and the full population. The comparison of partisanship yields a value of 0.11 , the comparison of candidacy type a value of 0.05 , and the comparison of electoral performance a value of 0.02 . The sample is representative of the full population on these three key characteristics.

Table Al. 2016 Welsh Candidate Study sample

\begin{tabular}{rccc}
\hline & & Candidates (\%) & Sample (\%) \\
\hline Partisanship & & \\
& Plaid Cymru & 14.0 & 16.2 \\
UKIP Wales & 9.2 & 12.6 \\
Welsh Conservative Party & 16.4 & 20.7 \\
Welsh Labour & 12.5 & 9.0 \\
Welsh Liberal Democrats & 10.7 & 11.7 \\
& Other & 37.2 & 29.7 \\
Candidacy type & Duncan index $=0.11$ \\
& & & \\
& & & \\
& Constituency & 33.5 & 31.5 \\
& Regional list & 45.5 & 42.3 \\
Dual & 21.0 & 26.1 \\
& & Duncan index $=0.05$ \\
Electoral performance & \multicolumn{2}{c}{10.8} \\
& Successful & 13.1 & 89.2 \\
& Unsuccessful & 86.9 & Duncan index $=0.02$ \\
\hline
\end{tabular}




\section{References}

Arnorsson, A. and Zoega, G. (2018) On the causes of Brexit. European Journal of Political Economy 55: 301-323.

Awan-Scully, R. (2016a) Voting intentions for Westminster and the EU referendum. Available at: https://blogs.cardiff.ac.uk/electionsinwales/2016/02/15/voting-intentions-for-westminsterand-the-eu-referendum (accessed 30 September 2019).

Awan-Scully, R. (2016b) General election and EU referendum voting intentions: The latest Welsh evidence. Available at: https://blogs.cardiff.ac.uk/electionsinwales/2016/03/22/generalelection-and-eu-referendum-voting-intentions-the-latest-welsh-evidence (accessed 30 September 2019).

Awan-Scully, R. (2018) 2016 Welsh Election Study. Available at: https://github.com/WelshElectionStudy/2016-Welsh-Election-Survey (accessed 03 October 2019).

Becker, S.O., Fetzer, T. and Novy, D. (2017) Who voted for Brexit? A comprehensive district-level analysis. Economic Policy 32(92): 601-650.

Bromley-Davenport, H., MacLeavy, J. and Manley, D. (2018) Brexit in Sunderland: The production of difference and division in the UK referendum on European Union membership. Environment and Planning C: Politics and Space OnlineFirst.

Carl, N., Dennison, J. and Evans, G. (2019) European but not European enough: An explanation for Brexit. European Union Politics 20(2): 282-304.

Clarke, H.D., Goodwin, M. and Whiteley, P. (2017) Why Britain voted for Brexit: An individual-level analysis of the 2016 referendum vote. Parliamentary Affairs 70: 439-464.

Clarke, S. and Whittaker, M. (2016) The importance of place: Explaining the characteristics underpinning the Brexit vote across different parts of the UK. Available at: https://www.resolutionfoundation.org/app/uploads/2016/07/Brexit-vote-v4.pdf (accessed 03 June 2019).

Colantone, I. and Stanig, P. (2018) Global competition and Brexit. American Political Science Review 112(2): 201-218. 
Cowley, P. and Stuart, M. (2012) The Cambusters: The Conservative European Union referendum rebellion of October 2011. Political Quarterly 83(2): 402-406.

Crines, A.S., Jeffery, D. and Heppell, T. (2018) The British Labour Party and leadership election mandate(s) of Jeremy Corbyn: Patterns of opinion and opposition within the parliamentary Labour Party. Journal of Elections, Public Opinion and Parties 28(3): 361-379.

Curtice, J. (2017) Why Leave won the EU Referendum. Journal of Common Market Studies 55: 1937.

Evans, G., Fieldhouse, E., Green, J., Schmitt, H., van der Eijk, C., Mellon, J. and Prosser, C. (2016) British Election Study Internet Panel Wave 8 (2016 EU Referendum Study, Daily Campaign Survey). DOI: $10.15127 / 1.293723$.

Goodwin, M. and Heath, O. (2016) The 2016 referendum, Brexit and the left behind: An aggregatelevel analysis of the result. The Political Quarterly 323-332.

Goodwin, M. and Milazzo, C. (2017) Taking back control? Investigating the role of immigration in the 2016 vote for Brexit. The British Journal of Politics and International Relations 19(3): 450-464.

Henderson, A., Jeffery, C., Liñeira, R., Scully, R., Wincott, D. and Wyn Jones, R. (2016) England, Englishness and Brexit. The Political Quarterly 87(2): 187-199.

Henderson, A., Jeffery, C., Wincott, D. and Wyn Jones, R. (2017) How Brexit was made in England. The British Journal of Politics and International Relations 19(4): 631-646.

Heppell, T. (2013) Cameron and liberal conservatism: Attitudes within the parliamentary Conservative Party and Conservative ministers. The British Journal of Politics and International Relations 15: 340-361.

Heppell, T., Crines, A. and Jeffery, D. (2017) The United Kingdom referendum on European Union membership: The voting of Conservative parliamentarians. Journal of Common Market Studies 55(4): 762-778.

Hobolt, S. (2016) The Brexit vote: A divided nation, a divided continent. Journal of European Public Policy 23(9): 1259-1277. 
Hug, S. (2013) Parliamentary voting. In: W.C. Muller and H.M. Narud (eds.) Party governance and party democracy. New York: Springer, pp. 137-158.

Lee, N., Morris, K. and Kemeny, T. (2018) Immobility and the Brexit vote. Cambridge Journal of Regions, Economy and Society 11: 143-163.

Lynch, P. and Whitaker, R. (2013) Where there is discord, can they bring harmony? Managing intraparty dissent on European integration in the Conservative Party. The British Journal of Politics and International Relations 15(3): 317-329.

Lynch, P. and Whitaker, R. (2018) All Brexiteers now? Brexit, the Conservatives and party change. British Politics 13: 31-47.

Moore, L. (2018) Policy, office and votes: Conservative MPs and the Brexit referendum. Parliamentary Affairs 71: 1-27.

Matti, J. and Zhou, T. (2017) The political economy of Brexit: Explaining the vote. Applied Economics Letters 24(16): 1131-1134.

PoliticsHome (2016) MP Referendum Stance. Available at: http://downloads2.dodsmonitoring.com/downloads/2016/EU2016/MPReferendumStance.xlsx (accessed 03 June 2019).

Schwarz, D., Traber, D. and Benoit, K. (2017) Estimating intra-party preferences: Comparing speeches to votes. Political Science Research and Methods 5(2): 379-396.

Swales, K. (2016) Understanding the Leave vote. Available at: https://whatukthinks.org/eu/wpcontent/uploads/2016/12/NatCen_Brexplanations-report-FINAL-WEB2.pdf(accessed 03 June 2019).

Trumm, S. (2015) Voting procedures and parliamentary representation in the European Parliament. Journal of Common Market Studies 53(5): 1126-1142.

Trumm, S. (2018) Representation in Wales: An empirical analysis of policy divisions between voters and candidates. The British Journal of Politics and International Relations 20(2): 425-440.

Vasilopoulou, S. (2016) EU Euroscepticism and the Brexit referendum. The Political Quarterly 87(2): 219-227. 
Vasilopoulou, S. and Keith, D. (2019) Renegotiation versus Brexit: The question of the UK's constitutional relationship with the EU. Journal of Common Market Studies 57(3): 486-501.

Vasilopoulou, S. and Talving, L. (2019) Opportunity or threat? Public attitudes towards EU freedom of movement. Journal of European Public Policy 26(6): 805-823.

Vasilopoulou, S. and Wagner, M. (2017) Fear, anger and enthusiasm about the European Union:

Effects of emotional reactions on public preferences towards European integration. European Union Politics 18(3): 382-405.

Wales Governance Centre (2016) Wales and the EU referendum: Estimating Wales' net contribution to the European Union. Available at:

www.cardiff.ac.uk/_data/assets/pdf_file/0010/1288513/Estimating-Wales-Net-Contributionto-the-European-Union.pdf (accessed 03 June 2019). 
Table 1. Expectations

\begin{tabular}{|c|c|}
\hline & Leave vote \\
\hline Gender & + \\
\hline \multicolumn{2}{|l|}{$\mathrm{Age}^{\wedge}$} \\
\hline $35-54$ & + \\
\hline $55+$ & + \\
\hline Education & - \\
\hline \multicolumn{2}{|l|}{ Occupation^^$^{\wedge}$} \\
\hline Professional/technical & - \\
\hline Managerial & - \\
\hline Ideological position & + \\
\hline Wales democracy & - \\
\hline UK democracy & - \\
\hline EU democracy & + \\
\hline EU influence & + \\
\hline Economy & - \\
\hline Immigration & + \\
\hline Past AM & - \\
\hline
\end{tabular}

$\wedge$ Reference category is "18-34".

$\wedge^{\wedge}$ Reference category is "non-specialist". 
Table 2. Who voted Leave?

\begin{tabular}{|c|c|}
\hline & Leave vote \\
\hline Gender & $-0.07(0.87)$ \\
\hline \multicolumn{2}{|l|}{$\mathrm{Age}^{\wedge}$} \\
\hline $35-54$ & $-0.82(1.67)$ \\
\hline $55+$ & $-0.34(1.44)$ \\
\hline Education & $1.45(1.20)$ \\
\hline \multicolumn{2}{|l|}{ Occupation^^ } \\
\hline Professional/technical & $-2.93 * *(1.07)$ \\
\hline Managerial & $-3.12 *(1.46)$ \\
\hline Ideological position & $0.13(0.17)$ \\
\hline Wales democracy & $-1.01(0.60)$ \\
\hline UK democracy & $-0.85(0.57)$ \\
\hline EU democracy & $2.93 * *(0.57)$ \\
\hline EU influence & $3.14 * *(0.89)$ \\
\hline Economy & $0.22(0.97)$ \\
\hline Immigration & $3.73 * *(1.38)$ \\
\hline Past AM & $0.34(1.19)$ \\
\hline Constant & $-7.95 * *(2.28)$ \\
\hline Observations & 111 \\
\hline McFadden's R ${ }^{2}$ & 0.68 \\
\hline Log likelihood & -25 \\
\hline
\end{tabular}


Leave vote $(\%)$

\begin{tabular}{rrr}
\hline Occupation & & \\
& Non-specialist & 64.0 \\
& Mrofessional/technical & 41.6 \\
Managerial & 40.1 \\
$\Delta$ (non-specialist v. professional) & 22.4 \\
$\Delta$ (non-specialist v. managerial) & 23.9 \\
EU democracy & \\
& Very satisfied & 0.1 \\
Fairly satisfied & 7.3 \\
Not very satisfied & 31.3 \\
Not at all satisfied & 67.1 \\
$\Delta($ min v. max) & 67.0 \\
EU influence & Too little & 6.6 \\
& About right & 28.1 \\
Too much & 60.2 \\
Immigration & $\Delta$ (min v. max) & 53.6 \\
& Not mentioned & 41.6 \\
Mentioned & 69.7 \\
& $\Delta($ min v. max $)$ & 28.1 \\
\hline
\end{tabular}


Table 4. Leave support among candidates and voters

\begin{tabular}{lcc}
\hline Party & Candidates $(\%)$ & Voters $(\%)$ \\
\hline Plaid Cymru & 5.6 & 26.3 \\
UKIP Wales & 100 & 96.1 \\
Welsh Conservative Party & 69.6 & 64.4 \\
Welsh Labour & 0.0 & 25.7 \\
Welsh Liberal Democrats & 0.0 & 21.6 \\
Other & 69.7 & 22.1 \\
\hline
\end{tabular}

